OPEN ACCESS

Edited by:

Victor Manuel Navas-López, Hospital Materno-Infantil, Spain

Reviewed by:

Christiane Sokollik,

University Children's Hospital

Bern, Switzerland

Vrinda Bhardwaj,

Children's Hospital of Los Angeles,

United States

Rafael Martín-Masot,

Regional University Hospital of

Malaga, Spain

*Correspondence:

Eileen Crowley

Eileen.Crowley@/hsc.on.ca

Specialty section:

This article was submitted to

Pediatric Gastroenterology,

Hepatology and Nutrition,

a section of the journal

Frontiers in Pediatrics

Received: 30 January 2021 Accepted: 09 April 2021

Published: 26 May 2021

Citation:

Kapoor A and Crowley E (2021)

Advances in Therapeutic Drug

Monitoring in Biologic Therapies for

Pediatric Inflammatory Bowel Disease.

Front. Pediatr. 9:661536.

doi: 10.3389/fped.2021.661536

\section{Advances in Therapeutic Drug Monitoring in Biologic Therapies for Pediatric Inflammatory Bowel Disease}

\author{
Akshay Kapoor and Eileen Crowley* \\ Division of Pediatric Gastroenterology, Hepatology, and Nutrition, London Health Sciences Centre, Children's Hospital \\ Western Ontario, Western University, London, ON, Canada
}

In the current era of treat-to-target strategies, therapeutic drug monitoring (TDM) has emerged as a potential tool in optimizing the efficacy of biologics for children diagnosed with inflammatory bowel disease (IBD). The incorporation of TDM into treatment algorithms, however, has proven to be complex. "Proactive" TDM is emerging as a therapeutic strategy due to a recently published pediatric RCT showing a clear benefit of "proactive" TDM in anti-TNF therapy. However, target therapeutic values for different biologics for different disease states [ulcerative colitis (UC) vs. Crohn's disease (CD)] and different periods of disease activity (induction vs. remission) require further definition. This is especially true in pediatrics where the therapeutic armamentarium is limited, and fixed weight-based dosing may predispose to increased clearance leading to decreased drug exposure and subsequent loss of response (pharmacokinetic and/or immunogenic). Model-based dosing for biologics offers an exciting insight into dose individualization thereby minimizing the chances of losing response. Similarly, point-of-care testing promises real-time assessment of drug levels and individualized decision-making. In the current clinical realm, TDM is being used to prolong drug durability and efficacy and prevent loss of response. Ongoing innovations may transform it into a personalized tool to achieve optimal therapeutic endpoints.

Keywords: pediatric, inflammatory bowel disease, therapeutic drug monitoring, biologics, precision medicine

\section{INTRODUCTION}

Biologic agents have revolutionized the treatment paradigm of pediatric inflammatory bowel disease (pIBD). Initially utilized as a second-line therapy in case of treatment failure with conventional medication (step-up approach), they are now considered as a primary induction option for children with active perianal fistulizing disease, in combination with targeted surgical intervention, as well as in children at risk of poor outcomes (top-down approach) $(1,2)$.

Infliximab (IFX) was the first licensed anti-tumor necrosis factor (TNF) approved for pediatric use in 2006 for treating Crohn's disease (CD) (3). It was approved for use in the pediatric population for ulcerative colitis in 2010 (4). Adalimumab, which is a fully humanized monoclonal antibody, was approved for pediatric CD in 2012 (5) and has been recently approved by the US FDA for moderate to severe pediatric UC based on the ENVISION I phase 3 study (6). With the advent of gut selective anti-integrin molecules like vedolizumab, which offers promising clinical response in 
colonic IBD with negligible side effects, the choice of biologic agents is increasing (7). Recently, ustekinumab, which is a biologic targeting the IL-12/23 pathway, has been approved for use in adult IBD (CD and UC) $(8,9)$ and is being used off label on a compassionate basis in pediatric IBD centers (10).

Therapeutic drug monitoring (TDM) which involves measuring drug concentration and antibody levels to optimize biologic exposure, thereby increasing efficacy and decreasing possible toxicity, is an essential tool in the arsenal to treat pIBD (Figure 1). Despite its widespread use in clinical practice, there are subtle issues which need to be addressed before uniform guidelines can be formulated. Questions around timing of TDM (proactive vs. reactive), frequency (during induction, maintenance, or both), and drug thresholds (underdosage vs. futility level) need to be aligned with the current treat-to-target paradigms (clinical, endoscopic, and histologic remission).

\section{METHODOLOGY}

A review of the medical literature incorporating keywords was performed on databases (to include PubMed, Medline, Embase, Scopus, Web of Sciences). Attention was given to previous reviews and seminal articles and an attempt was made to include recent advances and developments in the field. All relevant articles up to December 2020 were included.

\section{Reactive vs. Proactive TDM}

Reactive testing is performed in the setting of active disease/flare/intolerance to the drug. It helps in delineating the possible cause of loss of response (LOR) and in possibly formulating a strategy to counteract it (Figures 2, 3). Intuitively, higher trough levels (TL) of the drug equate to higher exposure and should theoretically result in better clinical outcomes. This has been shown with different anti-TNFs in seminal adult studies (11-13). However, most of these studies were retrospective post hoc analyses. Recently published prospective studies seem to have confirmed this trend $(14,15)$. Similarly, pediatric retrospective studies performed during the maintenance phase demonstrate an inverse association between trough level and antibody formation (16-18). Prospective pediatric studies have looked at infliximab (IFX) levels in the postinduction phase (Table 1). Adedokun et al. (19) in a phase 3 RCT concluded that higher IFX TL at week 8 correlated with better clinical and histological outcomes in children with moderate to severe UC. Singh et al. (20) highlighted the importance of a week $14 \mathrm{TL}$ as an indicator for clinical and endoscopic remission at week 54. TLs performed during the induction phase have the added benefit of differentiating between a mechanistic failure (primary non-response to anti-TNF) vs. a pharmacokinetic failure due to inadequate dosing and/or increased clearance (21).

Proactive TDM is performed in patients with quiescent disease to decrease the risk of disease relapse, treatment failure, and drug immunogenicity. It also may help in optimizing monotherapy with the biologic agent without the need for an immunomodulator, thereby avoiding potential toxic therapy. This has been examined in adult studies carried out by Lega et al. (22) and post hoc analysis of the SONIC trial (23). Papamichael et al. (24) in a multicentric retrospective study showed benefit for the proactive TDM approach with regard to treatment failure, disease-related hospitalization, surgery, and infusion reactions. The results of the two randomized control trials completed in adults, comparing proactive TDM to empiric optimization, have been disappointing. The TAXIT study (25) randomized IBD (UC and $\mathrm{CD}$ ) patients on stable maintenance therapy with IFX to receive further dosing based on proactive monitoring or clinical symptoms. Interestingly, all patients were dose optimized to a TL of $3-7 \mu \mathrm{g} / \mathrm{ml}$ prior to randomization. At the end of 12 months, there was no difference between the groups with regard to clinical/biochemical remission. There was also no differences noted with regard to surgery and corticosteroid-free remission between the groups. The TAILORIX trial (26) included biologic naive $\mathrm{CD}$ adult patients starting IFX therapy and randomized them to three arms based on clinical symptoms alone, clinical symptoms and biomarkers, and clinical symptoms, biomarker, and/or IFX trough levels. Dose escalation of IFX was based on predefined criteria in the first two groups. The primary endpoint of the study was corticosteroid-free clinical remission, fistulae, or need for surgery between weeks 22 and 54. There was no difference between the groups with regard to the primary or secondary endpoints. The PAILOT (27) study is the only pediatric RCT comparing proactive and reactive TDM using adalimumab as the biologic of choice. The proactive approach demonstrated a clear benefit with regard to corticosteroid-free clinical remission between weeks 8 and 72. A recent retrospective pediatric paper showed the benefit of a proactive anti-TNF TDM approach in improving outcomes related to steroid-free clinical remission (28).

The AGA guidelines issued in 2017 recommended the use of reactive TDM to guide treatment decisions based on a very low grade of evidence; however, it refrained from making any recommendations on proactive TDM (29). A second guideline issued as a result of a Delphi process among 25 international IBD experts recommended reactive TDM for both primary non-response (PNR) and LOR. However, it also recommended proactive TDM for patients in remission immediately post induction and those on stable maintenance, to save costs (30). Systematic reviews and meta-analysis performed to resolve this deadlock have consistently shown no clear benefit of any TDM strategy over empiric optimization. The reviews have shown a consistent cost benefit with a reactive TDM strategy vs. empiric escalation (31) and drug durability benefit with the proactive strategy $(32,33)$. This assumes greater importance in pediatrics as IBD specialists try to factor in insurance coverage and payorpayee concerns into pharmacotherapeutic decision-making (34).

\section{TDM and the Newer Biologics}

The $\alpha 4 \beta 7$ anti-integrin vedolizumab (VDZ) has been documented to have an exposure-response relationship similar to the anti-TNFs for both UC (GEMINI-1) (35) and CD (GEMINI-2) (36). Post hoc analysis of the GEMINI trials completed by Rosario showed that remission rates associated with TL $<17 \mu \mathrm{g} / \mathrm{ml}$ for UC and $<16 \mu \mathrm{g} / \mathrm{ml}$ for CD were similar to placebo (37). These findings were subsequently confirmed in two real-world cohort studies. In a Belgian study by Dreesen 

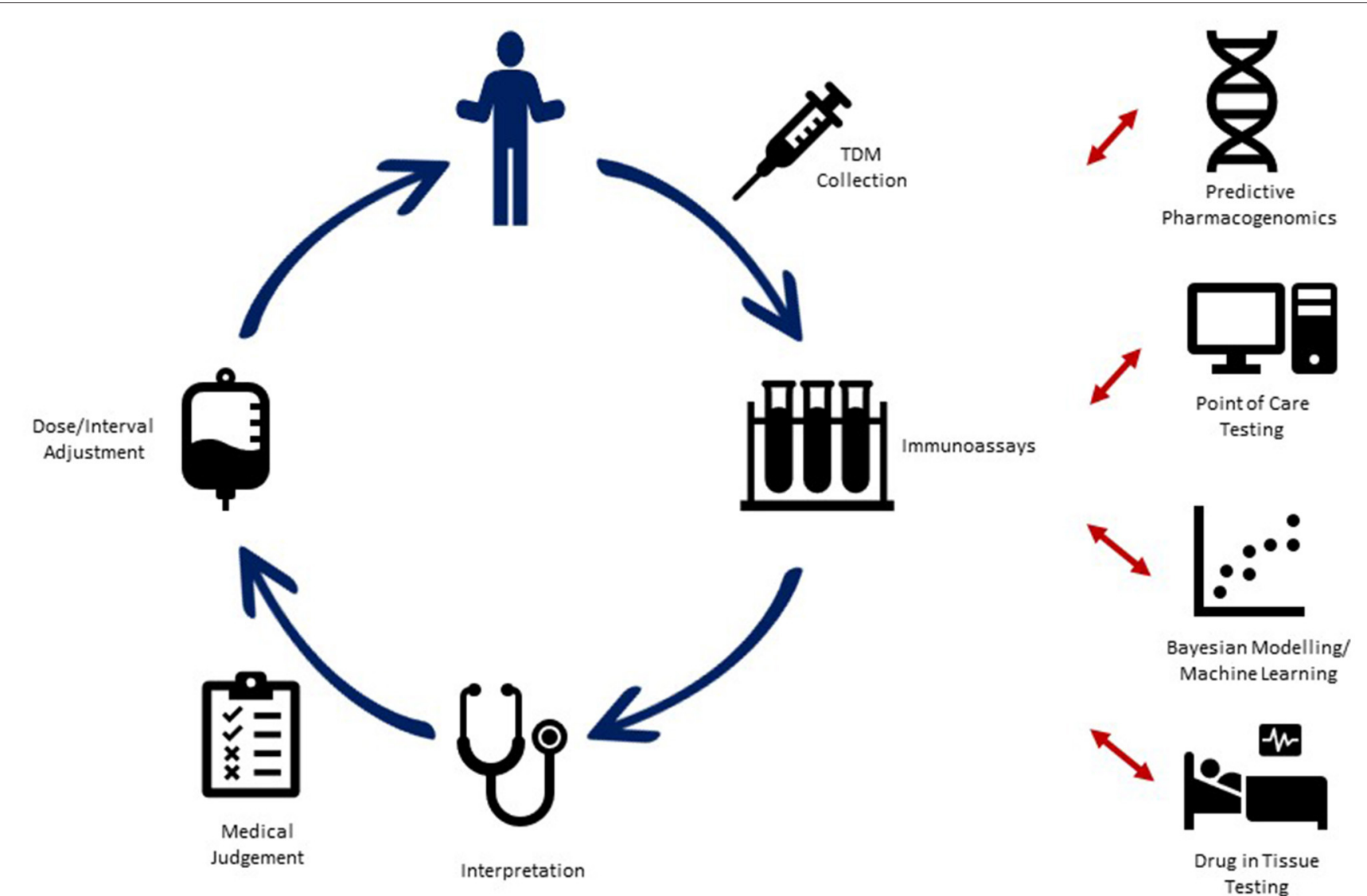

FIGURE 1 | Current utilization of therapeutic drug monitoring (TDM) in pediatric IBD, along with proposed advances for novel TDM strategies into the future.

et al. (38), cutoff points for trough levels were calculated using AUROC during both induction and maintenance. Similarly, Ungaro et al. (39) confirmed that higher TLs of VDZ were associated with steroid-free clinical remission.

The GEMINI trials also showed the low immunogenic potential of VDZ with persistent anti-drug antibody rates $<1 \%$ $(31,32)$. This has been confirmed in subsequent studies wherein adding an immunomodulator to VDZ therapy neither enhanced drug levels nor regained therapeutic response (40). Studies have shown near complete saturation of the $\alpha 4 \beta 7$ at drug levels as low as $1 \mu \mathrm{g} / \mathrm{ml}$; therefore, it is currently unclear as to how dose optimization may help in recapturing therapeutic response (41). A recent abstract presented at the Digestive Diseases Week (DDW) virtual meeting suggested that colonic tissue VDZ concentration varies inversely with the severity of inflammation. Thus, increasing the TL might enable more drug to penetrate the inflamed tissue and help with clinical remission/endoscopic healing (42). While evidence is emerging that TL for VDZ may be associated with clinical and endoscopic remission (43), there are no clinical guidelines regarding the levels that need to be targeted. The ECCO-ESGAR committee recommends TDM for VDZ whenever available (44). Studies on pediatric TDM with respect to VDZ are limited. A recent Dutch study highlighted the exposure-efficacy relationship of VDZ in a pediatric IBD population which had failed anti-TNF. The authors concluded that a lower TL of VDZ in Crohn's disease patients vs. UC/IBD$\mathrm{U}$ was due to the transmural nature of the disease and may benefit from proactive TDM and subsequent higher dosing (45).

Ustekinumab (UST) is an IL-12/23 inhibitor which works by blocking the common p40 subunit. The exposure-efficacy relationship for UST dosing was proven in the pivotal studies IM-UNITI and UNIFI in CD and UC, respectively $(8,9)$. A real-world study by Battat et al. (46) showed that a TL $>4.5 \mu \mathrm{g} / \mathrm{ml}$ during maintenance was associated with a biomarker and endoscopic response. Of note, the majority of patients in this study had been dose optimized to receive UST every 4 weeks, against the conventional 8-week dosing. Adedokun et al. in their study with more conventional eight-weekly maintenance dosing in adult CD patients showed a TL $>0.8 \mu \mathrm{g} / \mathrm{ml}$ to be associated with prolonged clinical and endoscopic remission (47). The immunogenic potential of UST, similar to VDZ, is also quite low; consequently, the addition of azathioprine/methotrexate is seldom required. There is still a lot of variability in the optimization protocols for UST. The seminal extension study (IM-UNITI) (48) suggested 12-weekly maintenance dosing in biologic naive patients and 8-weekly dosing in anti-TNF therapy-experienced patients. Other ongoing trials include STARDUST (treat-to-target vs. routine case management in 
TABLE 1 | Summary of pediatric studies utilizing TDM for biologic efficacy.

\begin{tabular}{|c|c|c|c|c|c|c|c|c|c|c|}
\hline Study & Type & Year & Drug & $\begin{array}{c}\text { Age (years) } \\
\text { Median (IQR) }\end{array}$ & $N$ & Type of IBD & Outcomes measured & Results & ADA & Assay \\
\hline $\begin{array}{l}\text { Adedokun et al. } \\
\text { (19) }\end{array}$ & $\begin{array}{l}\text { Prospective } \\
\text { randomized open } \\
\text { label }\end{array}$ & 2013 & IFX & $14.5(11.5-16)$ & 60 & UC & $\begin{array}{l}\text { IFX TL in children through } \\
\text { induction and maintenance }\end{array}$ & $\begin{array}{l}\text { PUCAI, Mayo score IFXw8: } \\
>41.1 \text { associated with CR and } \\
\mathrm{MH} \sim 93 \%\end{array}$ & 4/52 (8\%) & ELISA \\
\hline Singh et al. (20) & $\begin{array}{l}\text { Prospective } \\
\text { observational } \\
\text { cohort }\end{array}$ & 2014 & $\mathrm{IFX}$ & $11.4(6.6-18.4)$ & 46 & $\mathrm{CD} / \mathrm{UC}$ & $\begin{array}{l}\text { Postinduction TL, clinical } \\
\text { and endoscopic outcomes }\end{array}$ & $\begin{array}{l}\text { W14: } 5.1(3.1-7.5) \\
\text { W54: } 5.2(3.7-9.1) \\
\text { CR: } 4.7 \mu \mathrm{g} / \mathrm{ml} \text { vs. NR } 2.6 \mu \mathrm{g} / \mathrm{ml} \\
(p=0.03)\end{array}$ & $\begin{array}{l}\text { W14: } 10 \% \\
\text { W54: } 26 \%\end{array}$ & $\begin{array}{l}\text { ELISA } \\
\text { HMSA }\end{array}$ \\
\hline $\begin{array}{l}\text { Hoekman et al. } \\
\text { (77) }\end{array}$ & Prospective cohort & 2015 & $\mathrm{IFX}$ & $15(12.9-16.3)$ & 39 & $\mathrm{CD} / \mathrm{UC}$ & $\begin{array}{l}\text { Maintenance TL, clinical, } \\
\text { and biomarker remission }\end{array}$ & $\begin{array}{l}\mathrm{CR} \text { (median): } 3.5 \mu \mathrm{g} / \mathrm{ml} \text { vs. NR } \\
2.3 \mu \mathrm{g} / \mathrm{ml}(p=0.2) \\
\mathrm{TL} \sim \mathrm{CRP}(p<0.01) \\
\mathrm{TL} \sim \mathrm{fCal}(p<0.01)\end{array}$ & 4/32 (12\%) & ELISA \\
\hline $\begin{array}{l}\text { Zitomersky et al. } \\
\text { (78) }\end{array}$ & Cross-sectional & 2015 & $\mathrm{IFX}$ & $17.3 \pm 4.3$ & 134 & $\mathrm{CD} / \mathrm{UC}$ & $\begin{array}{l}\text { Impact of ADAs on trough } \\
\text { levels and clinical } \\
\text { parameters }\end{array}$ & $\begin{array}{l}A D A<5 \cup / m l: ~ 80 \% \\
A D A>5: 20 \% \\
A D A>10: 13 \% \\
A D A>12: 10 \% \\
\text { IFX TL + ADA }>5: 1 \mu \mathrm{g} / \mathrm{ml} \\
(1-9.3) \\
\text { IFX TL+ ADA }<5: 12.2 \mu \mathrm{g} / \mathrm{ml} \\
(7.6-25)\end{array}$ & $27 / 134(20 \%)$ & HMSA \\
\hline Sharma et al. (79) & $\begin{array}{l}\text { Post hoc analysis } \\
\text { of double-blind } \\
\text { randomized study }\end{array}$ & 2015 & Ada & $13.6(6-17)$ & 189 & $\mathrm{CD} / \mathrm{UC}$ & $\begin{array}{l}\text { Relationship of induction } \\
\text { and maintenance TL with } \\
\text { remission }\end{array}$ & $\begin{array}{l}\text { W4: CR }(14.5 \mu \mathrm{g} / \mathrm{ml}) \text { vs. NR } \\
(13.6 \mu \mathrm{g} / \mathrm{ml}), p=0.28 \\
\text { W26: CR }(11.3 \mu \mathrm{g} / \mathrm{ml}) \text { vs. NR } \\
(10.5 \mu \mathrm{g} / \mathrm{ml}), p=0.02 \\
\text { W52: CR }(13.3 \mu \mathrm{g} / \mathrm{ml}) \text { vs. NR } \\
(9.85 \mu \mathrm{g} / \mathrm{ml}), p=0.11\end{array}$ & 6/182 (3.3\%) & ELISA \\
\hline Minar et al. (80) & $\begin{array}{l}\text { Retrospective } \\
\text { cohort }\end{array}$ & 2016 & $\mathrm{IFX}$ & $12 \pm 4$ & 72 & $C D$ & TL for dose intensification & $\begin{array}{l}\text { Undetectable TL: } 24 \% \\
\text { TL <3: } 38 \% \\
\text { Dose intensification on basis of } \\
\text { TL: } 35 \%\end{array}$ & 14/72 (19\%) & $\begin{array}{l}\text { ELISA } \\
\text { HMSA }\end{array}$ \\
\hline Dubinsky et al. (81) & $\begin{array}{l}\text { Post hoc analysis } \\
\text { of double-blind } \\
\text { randomized study }\end{array}$ & 2016 & Ada & $\begin{array}{c}13.6 \text { (range } \\
6-17)\end{array}$ & 83 & $C D$ & $\begin{array}{l}\text { Clinical outcomes with dose } \\
\text { escalation based on TLs }\end{array}$ & $\begin{array}{l}\text { CR before dose increase TL } \\
9.8 \mu \mathrm{g} / \mathrm{ml} \\
\text { CR after dose increase TL: } \\
21 \mu \mathrm{g} / \mathrm{ml} \\
\text { Cre before dose increase TL: } 9.1 \\
\mu \mathrm{g} / \mathrm{ml} \\
\text { Cre after dose increase TL: } \\
19.1 \mu \mathrm{g} / \mathrm{ml}\end{array}$ & 6/182 (3.3\%) & ELISA \\
\hline Stein et al. (76) & Prospective cohort & 2016 & $\mathrm{IFX}$ & $\begin{array}{c}14.79 \\
(12.2-16.8)\end{array}$ & 77 & $C D$ & $\begin{array}{l}\text { Durability of biologic based } \\
\text { on W10 TL }\end{array}$ & $\begin{array}{l}\text { W10 TL } \\
\text { Off IFX at } 12 \text { months: } 8.7 \mu \mathrm{g} / \mathrm{ml} \\
\text { On IFX at } 12 \text { months: } 20.4 \mu \mathrm{g} / \mathrm{ml}\end{array}$ & $18 / 77(23 \%)$ & HMSA \\
\hline Choi et al. (16) & $\begin{array}{l}\text { Retrospective } \\
\text { cohort }\end{array}$ & 2017 & $\mathrm{IFX}$ & $14.7(9-18.8)$ & 39 & $\mathrm{CD} / \mathrm{UC}$ & $\begin{array}{l}\text { Maintenance TL and clinical } \\
\text { remission }\end{array}$ & $\begin{array}{l}\mathrm{CR} \text { (median): } 3.99 \mu \mathrm{g} / \mathrm{ml} \text { vs. NR } \\
\text { (median): } 0.88 \mu \mathrm{g} / \mathrm{ml}, p=0.02\end{array}$ & 7/39 (18\%) & ELISA \\
\hline
\end{tabular}


TABLE 1 | Continued

\begin{tabular}{|c|c|c|c|c|c|c|c|c|c|c|}
\hline Study & Type & Year & Drug & $\begin{array}{l}\text { Age (years) } \\
\text { Median (IQR) }\end{array}$ & $N$ & Type of IBD & Outcomes measured & Results & ADA & Assay \\
\hline $\begin{array}{l}\text { Merras-Salmio } \\
\text { et al. (17) }\end{array}$ & $\begin{array}{l}\text { Retrospective } \\
\text { cohort }\end{array}$ & 2017 & IFX & $14.8(12.5-16)$ & 146 & $\mathrm{CD} / \mathrm{UC}$ & $\begin{array}{l}\text { Maintenance TL and clinical } \\
\text { remission }\end{array}$ & $\begin{array}{l}\text { CR (median): } 3.7 \mu \mathrm{g} / \mathrm{ml} \text { vs. NR } \\
\text { (median): } 1.2 \mu \mathrm{g} / \mathrm{ml}, p=0.005\end{array}$ & $52 / 208(25 \%)$ & ELISA \\
\hline $\begin{array}{l}\text { Rolandsdotter } \\
\text { et al. (18) }\end{array}$ & $\begin{array}{l}\text { Retrospective } \\
\text { cohort }\end{array}$ & 2017 & IFX & $16(7-18)$ & 45 & $\mathrm{CD} / \mathrm{UC}$ & $\begin{array}{l}\text { Maintenance TL, clinical, } \\
\text { and biomarker remission }\end{array}$ & $\begin{array}{l}\mathrm{CR} \text { (median): } 7.2 \mu \mathrm{g} / \mathrm{ml} \text { vs. NR } \\
\text { (median): } 1.2 \mu \mathrm{g} / \mathrm{ml} p<0.05 \\
\mathrm{TL} \sim \mathrm{CRP}(p=0.008) \\
\mathrm{TL} \sim \operatorname{ESR}(p=0.003) \\
\mathrm{TL} \sim \text { albumin }(p=0.0005)\end{array}$ & $8 / 45(18 \%)$ & ELISA \\
\hline Chi et al. (82) & $\begin{array}{l}\text { Prospective } \\
\text { observational } \\
\text { cohort study }\end{array}$ & 2018 & IFX & $18.5 \pm 4.4$ & 223 & $\mathrm{CD} / \mathrm{UC}$ & $\begin{array}{l}\text { Combination IM + IFX } \\
\text { therapy and relation to TL } \\
\text { and ADA }\end{array}$ & $\begin{array}{l}\text { Combination TL: } 17 \pm \\
1.33 \mu \mathrm{g} / \mathrm{ml} \text { vs. monotherapy TL: } \\
13.18 \pm 1.26 \mu \mathrm{g} / \mathrm{ml}(p<0.01)\end{array}$ & $\begin{array}{l}9.5 \% \text { for combination } \\
\text { therapy vs. } 20 \% \text { on } \\
\text { monotherapy }\end{array}$ & HMSA \\
\hline $\begin{array}{l}\text { van Hoeve et al. } \\
\text { (83) }\end{array}$ & $\begin{array}{l}\text { Retrospective } \\
\text { cohort study }\end{array}$ & 2018 & IFX & $12.2(9.5-14.4)$ & 52 & $\mathrm{CD} / \mathrm{UC}$ & $\begin{array}{l}\text { Maintenance TL, clinical, } \\
\text { endoscopic, and biomarker } \\
\text { remission }\end{array}$ & $\begin{array}{l}\text { TL (remission vs. not) } p<0.01 \\
\text { for all } \\
\text { CR: } 5.4 \text { vs. } 4.2 \mu \mathrm{g} / \mathrm{ml} \\
\text { BR: } 5.2 \text { vs. } 4.2 \mu \mathrm{g} / \mathrm{ml} \\
\text { CR+BR: } 5.7 \mathrm{vs.} 4.4 \mu \mathrm{g} / \mathrm{ml} \\
\text { ER: } 6.5 \text { vs. } 3.2 \mu \mathrm{g} / \mathrm{ml}\end{array}$ & Not reported & \\
\hline Ohem et al. (84) & $\begin{array}{l}\text { Prospective } \\
\text { observational } \\
\text { study }\end{array}$ & 2018 & IFX & $12.6(10.5-15.1)$ & 65 & $C D$ & TL and biomarker remission & $\begin{array}{l}\text { TL for } \\
\text { CRP }<5 \mathrm{mg} / \mathrm{l}:>1.1 \mu \mathrm{g} / \mathrm{ml} \\
\text { fCal < } 100: 3.5 \mu \mathrm{g} / \mathrm{ml}\end{array}$ & $\begin{array}{l}\text { Low TL were } \\
\text { associated with high } \\
\text { ADA (OR 0.027) 95\% } \\
\text { Cl 0.009-0.077 }\end{array}$ & ELISA \\
\hline $\begin{array}{l}\text { van Hoeve et al. } \\
\text { (85) }\end{array}$ & $\begin{array}{l}\text { Retrospective } \\
\text { cohort study }\end{array}$ & 2019 & IFX & $11.6(8.8-13.9)$ & 35 & $\mathrm{CD} / \mathrm{UC}$ & $\begin{array}{l}\text { Postinduction TLs as } \\
\text { predictors of clinical and } \\
\text { biological remission at W52 }\end{array}$ & $\begin{array}{l}\text { Postinduction TL (remission vs. } \\
\text { not), } p<0.002 \\
\text { CR: } 4.6 \text { vs. } 1.5 \mu \mathrm{g} / \mathrm{ml} \\
\text { BR: } 4.6 \text { vs. } 2.6 \mu \mathrm{g} / \mathrm{ml} \\
\text { CR+BR: } 6.0 \text { vs. } 2.6 \mu \mathrm{g} / \mathrm{ml}\end{array}$ & Not reported & \\
\hline Assa et al. (27) & $\begin{array}{l}\text { Non-blinded } \\
\text { randomized } \\
\text { control trial }\end{array}$ & 2019 & Ada & $14.3 \pm 2.6$ & 78 & $C D$ & $\begin{array}{l}\text { Reactive vs. proactive drug } \\
\text { monitoring and relation with } \\
\text { sustained } \\
\text { corticosteroid-free CR }\end{array}$ & $\begin{array}{l}\text { CFCR (8-72 weeks) } \\
82 \% \text { in the proactive group vs. } \\
48 \% \text { in the reactive group }(p= \\
0.02) \\
\text { CFCR+BR: } 42 \% \text { in the proactive } \\
\text { group and } 12 \% \text { in the reactive } \\
\text { group }(p=0.03)\end{array}$ & 8/78 (10.2\%) & ELISA \\
\hline Choi et al. (86) & $\begin{array}{l}\text { Retrospective } \\
\text { cohort study }\end{array}$ & 2019 & IFX & 14.5 & 103 & $\mathrm{CD} / \mathrm{UC}$ & $\begin{array}{l}\text { Correlation of IFX levels with } \\
\text { hematological remission } \\
\text { (CRP, ESR, albumin, and } \\
\text { hematocrit) }\end{array}$ & $\begin{array}{l}\text { Week } 6 \text { IFX level } 9.82 \mu \mathrm{g} / \mathrm{ml} \text { was } \\
\text { required to maintain } \\
\text { CRP }<0.5 \text { (AUC } 0.88 \text { ) } \\
\text { Week } 14 \text { IFX level of } 1.28 \mu \mathrm{g} / \mathrm{ml} \\
\text { was required to maintain } \\
\text { CRP }<0.5 \text { (AUC 0.86) }\end{array}$ & Not reported & ELISA \\
\hline
\end{tabular}


TABLE 1 | Continued

\begin{tabular}{|c|c|c|c|c|c|c|c|c|c|c|}
\hline Study & Type & Year & Drug & $\begin{array}{c}\text { Age (years) } \\
\text { Median (IQR) }\end{array}$ & $N$ & Type of IBD & Outcomes measured & Results & ADA & Assay \\
\hline Naviglio et al. (87) & $\begin{array}{l}\text { Prospective } \\
\text { observational } \\
\text { study }\end{array}$ & 2019 & IFX & $14.4(11.6-16.2)$ & 49 & $\mathrm{CD} / \mathrm{UC}$ & $\begin{array}{l}\text { CR as defined by } \\
\text { PUCAI/PCDAl } \\
\text { IFX TL and ADA (only if TL } \\
<1.5 \text { ) at weeks } 6,14,22 \text {, } \\
\text { and } 54\end{array}$ & $\begin{array}{l}\text { CR week } 14,76.3 \% \\
\text { CR week } 54,73.9 \% \\
\text { IFX level at the end of induction } \\
\text { week } 14,>3.11 \mu \mathrm{g} / \mathrm{ml} \text { was } \\
\text { strongest predictor of } \mathrm{CR} \text { at } \\
\text { week } 54\end{array}$ & $10 / 49$ (20.4\%) & ELISA \\
\hline $\begin{array}{l}\text { Clarkston et al. } \\
\text { (88) }\end{array}$ & $\begin{array}{l}\text { Prospective } \\
\text { observational } \\
\text { study }\end{array}$ & 2019 & IFX & 14.4 & 72 & $C D$ & $\begin{array}{l}\text { CR: wPCDAl at the fourth } \\
\text { infusion } \\
\text { BR: }>50 \% \text { reduction in fCal } \\
\text { Maintenance IFX level > } \\
\mu \mathrm{g} / \mathrm{ml}\end{array}$ & $\begin{array}{l}\text { CR: } 64 \% \\
\text { BR: } 54 \% \\
\text { Start of maintenance }>5 \mu \mathrm{g} / \mathrm{ml} \text { : } \\
22 \% \\
\text { Infusion } 2 \text { level }>29 \mu \mathrm{g} / \mathrm{ml} \text { and } \\
\text { infusion } 3>18 \mu \mathrm{g} / \mathrm{ml} \text { strongly } \\
\text { associated with improved early } \\
\text { outcomes }\end{array}$ & Not reported & ELISA \\
\hline Gofin et al. (89) & $\begin{array}{l}\text { Retrospective } \\
\text { cohort study }\end{array}$ & 2020 & IFX and Ada & $12.6(10.1-14.2)$ & 197 & $C D$ & $\begin{array}{l}\text { Effect on disease outcomes } \\
\text { with TDM vs. without } \\
\text { Drug retention } \\
\text { Hospitalization rate/year } \\
\text { Treatment intensification } \\
\text { Surgical resection }\end{array}$ & $\begin{array}{l}\text { Longer retention time with TDM } \\
\text { Lower hospitalization rate with } \\
\text { TDM } \\
\text { Higher drug intensification rate } \\
\text { with TDM } \\
\text { No difference in surgical } \\
\text { outcomes }\end{array}$ & Not reported & ELISA \\
\hline Choi et al. (90) & $\begin{array}{l}\text { Prospective cohort } \\
\text { study }\end{array}$ & 2020 & ADA & $14.1 \pm 2.0$ & 17 & $C D$ & $\begin{array}{l}\text { CR based on PCDAl at } \\
\text { week } 16 \\
\text { MH at week } 16 \\
\text { HR at week } 16\end{array}$ & $\begin{array}{l}\text { Ada TL was higher in those with } \\
\text { MH ( } 13 \pm 6.5 \text { vs. } 6.2 \pm \\
2.6 \mu \mathrm{g} / \mathrm{ml} ; p=0.02) \\
\text { Ada TL was higher in those with } \\
\mathrm{HR}(17.9 \pm 5.3 \mathrm{vs} .6 .8 \pm \\
2.5 \mu \mathrm{g} / \mathrm{ml} ; p=0.02) \\
\text { Optimal TL for MH at week } 16 \text {, } \\
8.76 \mu \mathrm{g} / \mathrm{ml}\end{array}$ & $0 \%$ & ELISA \\
\hline
\end{tabular}

PUCAI, Pediatric UIcerative Colitis Activity Index; IFX, infliximab; Ada, adalimumab; ADA, anti-drug antibody; TL, trough level; CR, clinical remission; NR, non-remission; Cre, clinical response; BR, biomarker remission; ER, endoscopic remission; fCal, fecal calprotectin; CFCR, corticosteroid-free clinical remission; $M H$, mucosal healing: $H R$, histologic remission. 


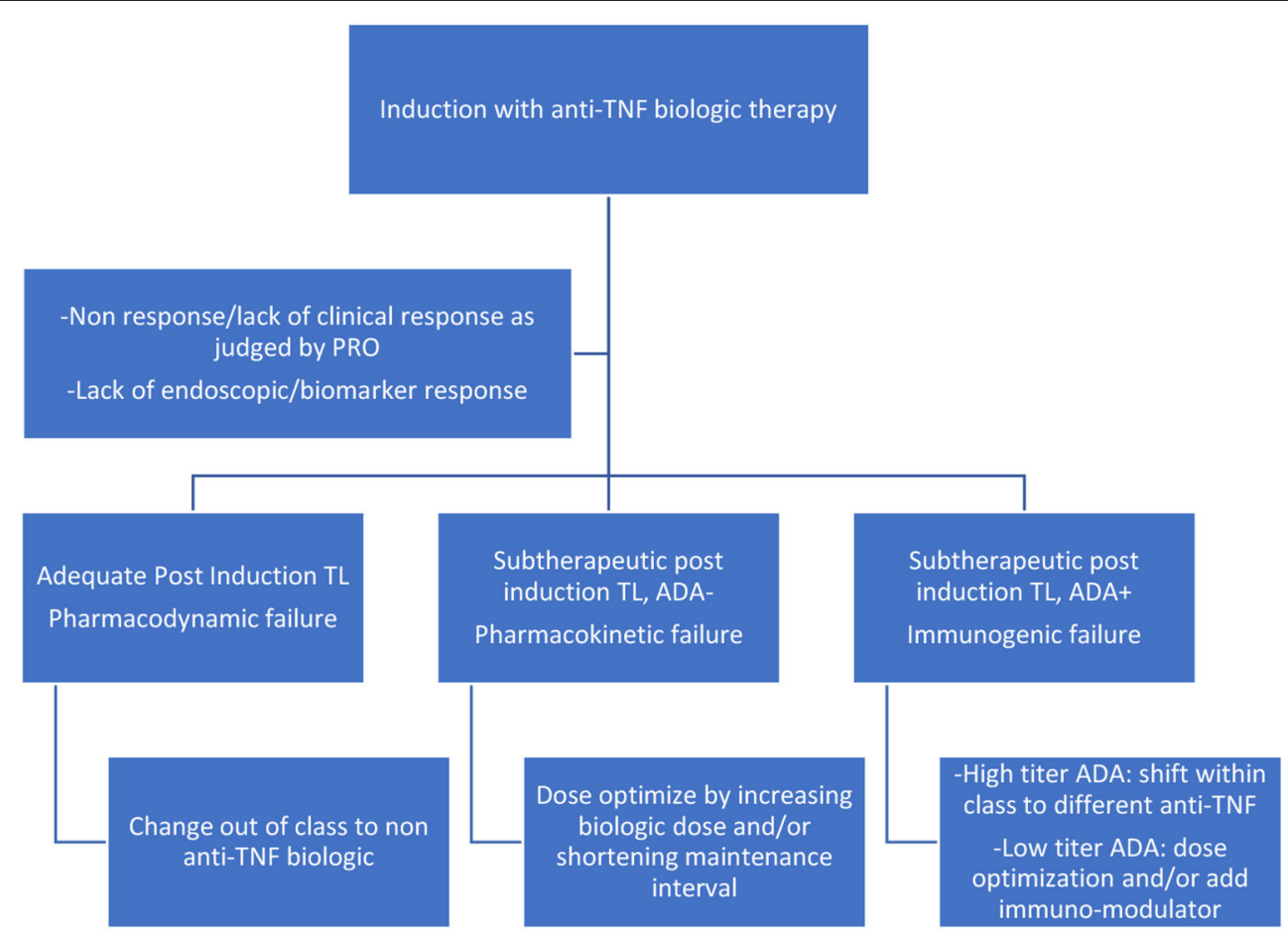

FIGURE 2 | Reactive drug monitoring scenarios during induction with anti-TNF agents.

CD patients on UST), POWER (efficacy and safety of UST reinduction therapy in patients with moderate and severe $C D$ ), and RESCUE (loss of response to UST treated with dose escalation), which might help in guiding formulation of desired TLs for different therapeutic endpoints (49).

Although, pediatric data are scarce, Dayan et al. (10) in a realworld pediatric cohort had reported $50 \%$ steroid-free remission (for biologic exposed) and 90\% steroid-free remission (biologic naive) at 1 year. There was no significant difference in the trough levels between the patients on or off steroids at 52 weeks.

\section{NOVEL TDM CONCEPTS}

\section{Personalized Medicine-Model-Informed Precision Dosing}

Currently, most of the biologic agents are administered on the basis of fixed dosing or weight-based dosing algorithms. Utilizing a TDM-based approach to look at pharmacokinetic profiles is helpful but not perfect as several factors (weight, disease load, disease stage, drug clearance) may influence the eventual TL for an individual. Adaptive dosing dashboards based on population pharmacokinetic models as a backbone are being increasingly used. The individual patient's characteristics and drug level measurements can be added on to this base model, to predict subsequent dosing requirement and frequency. While retrospective studies $(50,51)$ have validated the proof of concept, the PRECISION trial by Strik et al. $(52,53)$ was the first to employ this approach prospectively to IFX dosing. In this study, model-based dosing was superior to conventional dosing in maintaining remission. Subsequent studies performed by Dubinsky et al. $(54,55)$ have employed precision dosing models (Bayesian population-based pharmacokinetic model with weight, albumin, CRP, previous drug, and antibody levels added) to aim at prespecified individual TLs. Drug dosage and interval to next infusion was thus individualized based on this adaptive Bayesian modeling.

The Bayesian modeling approach seems to be a very promising development. Precision dosing has been used previously by clinical pharmacists for antibiotic dosing especially vancomycin and piperacillin-tazobactum $(56,57)$. However, the modeling requirements for a chronic disease like IBD are different. The efficacy of the model depends on the number of variables incorporated, and it will require constant updating and streamlining. Also, the target TL which the model aims to achieve is a moving target which varies with the disease phenotype and the disease phase. Although, it has the potential to eventually decrease drug costs by permitting de-escalation, in the short term, it will require more manpower, training, and coordination between health care teams and the pharmaceutical industry. Finally, more RCTs are needed especially during the induction phase to prove that model-informed precision dosing will be beneficial when parameters like TL and ADA are not available.

\section{Point-of-Care Testing}

Drug levels are currently processed in labs and are usually processed in batches. This leads to an increased turnover time and is particularly challenging in certain disease states 


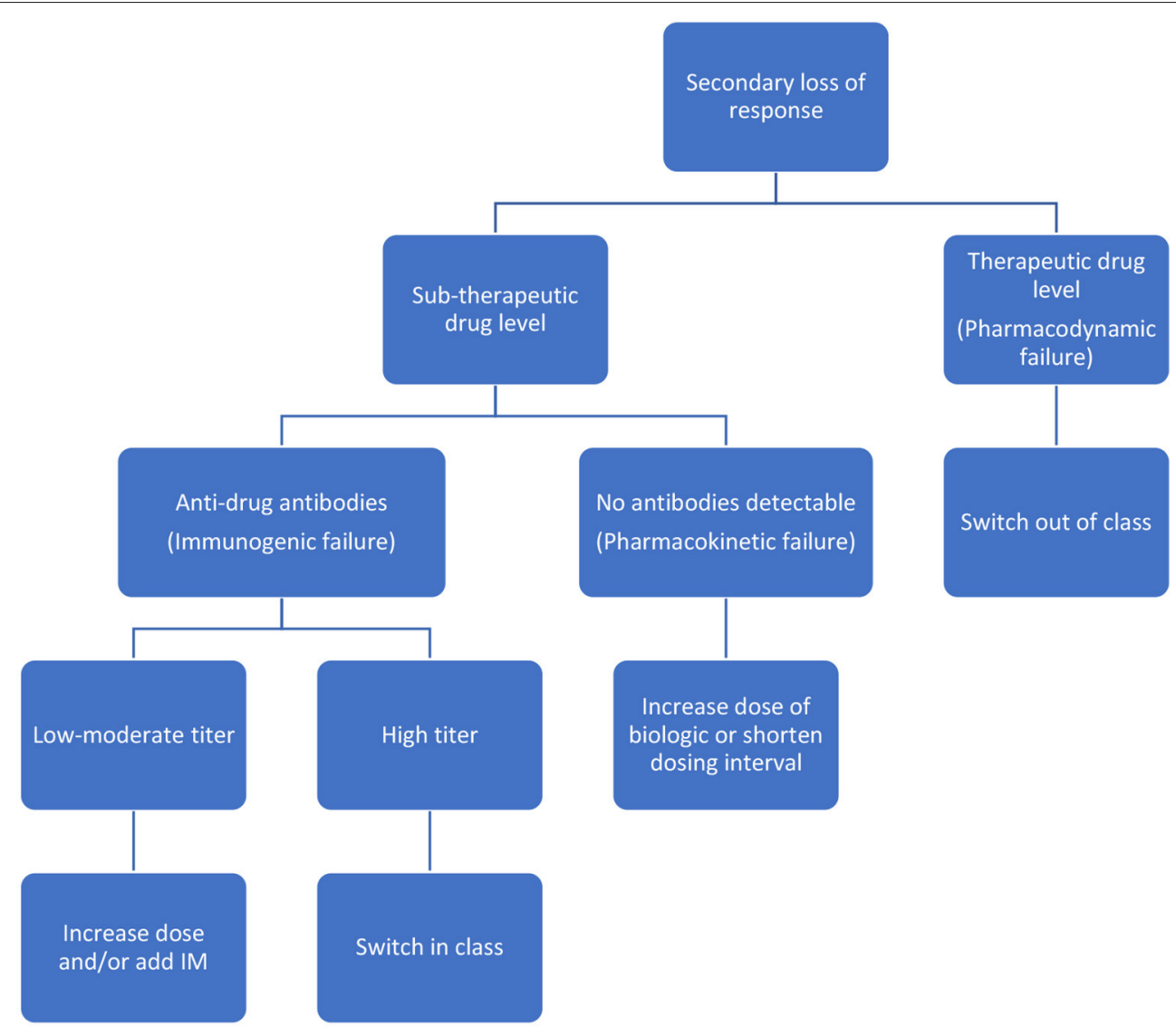

FIGURE 3 | Reactive drug monitoring scenarios and management strategies during maintenance.

associated with unpredictable pharmacokinetics (acute UC, fistulizing $\mathrm{CD}$ ) or during induction of therapy, especially when suspecting non-response.

Point-of-care assays can help in decreasing the turnaround time and help in providing an accurate, clinically relevant, real-time value to aid in clinical decision-making. Point-of-care assays for detecting IFX levels, adalimumab levels, and antiIFX antibodies are commercially available. However, they are limited by their ability to use serum instead of blood (58-60). As with other point-of-care tests, there are concerns around quality control, reliability, cost, and external validation. Some of these issues were addressed by a pilot project published as an abstract by Bossuyt et al. (61), wherein, they used an ultra-proactive point-of-care TDM approach to demonstrate applicability and effectiveness. Curci et al. (62) in a pediatric study validated two point-of-care IFX assays and compared them with previously validated ELISA assays for measuring trough levels. The group observed good intraclass as well as interclass correlation.

\section{Therapeutic Drug Monitoring in VEOIBD}

The proportion of children aged $<6$ years with a new diagnosis of IBD is increasing (63). The disease in younger children is more extensive, usually colonic and requires optimized treatment regimens, including the use of biologic drugs (64). It has been shown that standard IFX regimens and trough levels may not be applicable in this age group $(65,66)$ and may require more frequent escalation of therapy (67). This may be in part related to the size of the antigenic sink at the start of treatment or to the increased clearance related to the low body weight. Studies have also shown how weight-based dosing systematically underdoses children with low body weight (68). A recent case series by Assa et al. (69) showed how an accelerated induction protocol (increased dosing and interval shortening) helped to recapture response in a group of children with infantile IBD after they had experienced initial non-response/secondary LOR with IFX.

However, the overall clinical management of VEOIBD using biologics may be more complex than adjusting for age or weight. A recent study by Jongsma et al. (70) showed suboptimal $\mathrm{TL}$ for patients $<10$ vs. $>10$ years at the beginning of maintenance therapy. The former group also had a significantly higher antibody titer contributing to immunogenicity and, consequently, a lower TL. Multivariate analysis did not reveal a direct influence of age on TL. Proactive TDM in the younger age group did not seem to affect clinical remission rates at 52 weeks when compared with children $>10$ years. 


\section{Genomic Variants Influencing Trough Levels}

The PANTS consortium tried to look at genomic variants which could influence antibody formation and, consequently, lead to lower TL and loss of response for IFX and ADA. The group performed a GWAS to identify genomic variants that were associated with immunogenicity. They concluded that the HLADQA $1{ }^{*} 05$ allele significantly increased immunogenicity with a HR 1.9 (1.6-2.25) (71).

\section{Tissue Drug Levels in Pediatric IBD}

The ATLAS study demonstrated that anti-TNF concentration in tissue correlates with the degree of endoscopic inflammation, except in tissue with severe inflammation in which anti-TNF levels were lower (72). Tissue drug levels have not as yet been evaluated in pediatric IBD and may offer further insight into the individual's target trough level to achieve mucosal healing as a therapeutic endpoint.

\section{DISCUSSION}

The treat-to-target strategies recommended by the STRIDE (73) IOIBD working group aim at composite endpoints of both clinical/patient-reported remission as well as endoscopic and/or radiological healing. TDM may be intuitively linked to this goal but cannot be included in this approach due to failure of the seminal RCT studies TAXIT and TAILORIX to meet their primary endpoint/s. The lack of well-powered, prospective RCTs means that there is a knowledge gap which needs to be addressed. Meta-analysis and systematic reviews on the role of TDM are limited by the heterogeneity in study design, timing, and use of TDM, combination of different disease phenotypes, and endpoints of the different trials. Thus, many of the recommendations that emerge regarding the use of TDM for treat-to-target are based on low-grade evidence. Encouragingly, the recent PAILOT study has been helpful in proving that proactive TDM in biologic naive children on adalimumab did better than reactive TDM in the control group with regard to corticosteroid-free remission.

\section{REFERENCES}

1. Berg DR, Colombel JF, Ungaro R. The role of early biologic therapy in inflammatory bowel disease. Inflamm Bowel Dis. (2019) 25:1896-905. doi: 10.1093/ibd/izz059

2. van Rheenen PF, Aloi M, Assa A, Bronsky J, Escher JC, Fagerberg UL, et al. The medical management of paediatric Crohn's disease: an ECCO-ESPGHAN guideline update. J Crohns Colitis. (2020). doi: 10.1093/ecco-jcc/jjaa161. [Epub ahead of print].

3. Laharie D, Salzmann M, Boubekeur H, Richy F, Amouretti M, Quinton A, et al. Predictors of response to infliximab in luminal Crohn's disease. Gastroenterol Clin Biol. (2005) 29:145-9. doi: 10.1016/S0399-8320(05)80718-3

4. Hyams J, Damaraju L, Blank M, Johanns J, Guzzo C, Winter HS, et al. Induction and maintenance therapy with infliximab for children with moderate to severe ulcerative colitis. Clin Gastroenterol Hepatol. (2012) 10:391-9.e1. doi: 10.1016/j.cgh.2011.11.026

5. Hyams JS, Griffiths A, Markowitz J, Baldassano RN, Faubion WA Jr, Colletti RB, et al. Safety and efficacy of adalimumab for moderate to
Trough levels in clinical practice are intended for guidance. They can vary depending on the preselected endpoint (clinical remission vs. healing based on endoscopy and histology), disease severity, size of antigenic sink, and phase of treatment (induction vs. maintenance). Higher TLs may be aimed for in children with VEOIBD (61), those with perianal fistulae (74), severe UC (75), and during induction (20, 76). LOR scenarios are taxing for both the patient and the IBD physician. While drug levels are standardized ELISA tests that can be compared between different assays, the antidrug antibody tests are not standardized and various assays differ in cutoffs for low, intermediate, and high titer antibodies. Combining the lack of clarity on TLs and the varied recommendations on reactive and proactive TDM, this is an area of research that will require further clarification in the future. Proactive TDM is emerging as a new therapeutic strategy in pediatric patients; however, prospective interventional clinical trials looking at early induction and maintenance levels for novel biologic agents with endoscopic outcomes and/or composite surrogate outcomes are needed to advance our knowledge in the pediatric population.

Interest has been growing in personalizing treatment strategies by using predictive pharmacogenomics and machine learning to propose individualized treatment protocols. Exciting developments especially related to adaptive dosing dashboards utilizing Bayesian models herald the future of personalized medicine in IBD. If successful, they have the capacity to eliminate dosing tables and target TL values and possible inherent treatment bias of the physician. Coupled with pointof-care TDM and biomarker testing, this has the potential to revolutionize how pediatric IBD will be treated in the coming years.

\section{AUTHOR CONTRIBUTIONS}

$\mathrm{AK}$ and EC contributed to the design and implementation of this review article, to the analysis of the published studies, and to the writing of the manuscript. Both authors contributed to the article and approved the submitted version. severe Crohn's disease in children. Gastroenterology. (2012) 143:365-74.e2. doi: 10.1053/j.gastro.2012.04.046

6. Aloi M, Bramuzzo M, Arrigo S, Romano C, D’Arcangelo G, Lacorte D, et al. Efficacy and safety of adalimumab in pediatric ulcerative colitis: a reallife experience from the SIGENP-IBD registry. J Pediatr Gastroenterol Nutr. (2018) 66:920-5. doi: 10.1097/MPG.0000000000001883

7. Schneider AM, Weghuber D, Hetzer B, Entenmann A, Muller T, Zimmermann G, et al. Vedolizumab use after failure of TNF-alpha antagonists in children and adolescents with inflammatory bowel disease. BMC Gastroenterol. (2018) 18:140. doi: 10.1186/s12876-018-0868-x

8. Feagan BG, Sandborn WJ, Gasink C, Jacobstein D, Lang Y, Friedman JR, et al. Ustekinumab as induction and maintenance therapy for Crohn's disease. $N$ Engl J Med. (2016) 375:1946-60. doi: 10.1056/NEJMoa1602773

9. Sands BE, Sandborn WJ, Panaccione R, O’Brien CD, Zhang H, Johanns J, et al. Ustekinumab as induction and maintenance therapy for ulcerative colitis. $N$ Engl J Med. (2019) 381:1201-14. doi: 10.1056/NEJMoa1900750

10. Dayan JR, Dolinger M, Benkov K, Dunkin D, Jossen J, Lai J, et al. Real world experience with ustekinumab in children and young adults at a tertiary care 
pediatric inflammatory bowel disease center. J Pediatr Gastroenterol Nutr. (2019) 69:61-7. doi: 10.1097/MPG.0000000000002362

11. Adedokun OJ, Sandborn WJ, Feagan BG, Rutgeerts P, Xu Z, Marano CW, et al. Association between serum concentration of infliximab and efficacy in adult patients with ulcerative colitis. Gastroenterology. (2014) 147:1296-307.e5. doi: 10.1053/j.gastro.2014.08.035

12. Adedokun OJ, Xu Z, Marano CW, Strauss R, Zhang H, Johanns J, et al. Pharmacokinetics and exposure-response relationship of golimumab in patients with moderately-to-severely active ulcerative colitis: results from phase 2/3 pursuit induction and maintenance studies. J Crohns Colitis. (2017) 11:35-46. doi: 10.1093/ecco-jcc/jjw133

13. Vande Casteele N, Feagan BG, Vermeire S, Yassine M, Coarse J, Kosutic G, et al. Exposure-response relationship of certolizumab pegol induction and maintenance therapy in patients with Crohn's disease. Aliment Pharmacol Ther. (2018) 47:229-37. doi: 10.1111/apt.14421

14. Kennedy NA, Heap GA, Green HD, Hamilton B, Bewshea C, Walker GJ, et al. Predictors of anti-TNF treatment failure in anti-TNFnaive patients with active luminal Crohn's disease: a prospective, multicentre, cohort study. Lancet Gastroenterol Hepatol. (2019) 4:341-53. doi: 10.1016/S2468-1253(19)30012-3

15. Ungar B, Engel T, Yablecovitch D, Lahat A, Lang A, Avidan B, et al. Prospective observational evaluation of time-dependency of adalimumab immunogenicity and drug concentrations: the POETIC study. Am J Gastroenterol. (2018) 113:890-8. doi: 10.1038/s41395-018-0073-0

16. Choi SY, Kang B, Lee JH, Choe YH. Clinical use of measuring trough levels and antibodies against infliximab in patients with pediatric inflammatory bowel disease. Gut Liver. (2017) 11:55-61. doi: 10.5009/gnl16041

17. Merras-Salmio L, Kolho KL. Clinical use of infliximab trough levels and antibodies to infliximab in pediatric patients with inflammatory bowel disease. J Pediatr Gastroenterol Nutr. (2017) 64:272-8. doi: 10.1097/MPG.0000000000001258

18. Rolandsdotter H, Marits P, Sundin U, Wikstrom AC, Fagerberg UL, Finkel $\mathrm{Y}$, et al. Serum-Infliximab trough levels in 45 children with inflammatory bowel disease on maintenance treatment. Int J Mol Sci. (2017) 18:575. doi: 10.3390/ijms18030575

19. Adedokun OJ, Xu Z, Padgett L, Blank M, Johanns J, Griffiths A, et al. Pharmacokinetics of infliximab in children with moderateto-severe ulcerative colitis: results from a randomized, multicenter, open-label, phase 3 study. Inflamm Bowel Dis. (2013) 19:2753-62. doi: 10.1097/01.MIB.0000435438.84365.f7

20. Singh N, Rosenthal CJ, Melmed GY, Mirocha J, Farrior S, Callejas S, et al. Early infliximab trough levels are associated with persistent remission in pediatric patients with inflammatory bowel disease. Inflamm Bowel Dis. (2014) 20:1708-13. doi: 10.1097/MIB.0000000000000137

21. Papamichael K, Vande Casteele N, Ferrante M, Gils A, Cheifetz AS. therapeutic drug monitoring during induction of anti-tumor necrosis factor therapy in inflammatory bowel disease: defining a therapeutic drug window. Inflamm Bowel Dis. (2017) 23:1510-5. doi: 10.1097/MIB.00000000000 01231

22. Lega S, Phan BL, Rosenthal CJ, Gordon J, Haddad N, Pittman N, et al. Proactively optimized infliximab monotherapy is as effective as combination therapy in IBD. Inflamm Bowel Dis. (2019) 25:134-41. doi: 10.1093/ibd/izy203

23. Colombel JF, Adedokun OJ, Gasink C, Gao LL, Cornillie FJ, D'Haens GR, et al. Combination therapy with infliximab and azathioprine improves infliximab pharmacokinetic features and efficacy: a post hoc analysis. Clin Gastroenterol Hepatol. (2019) 17:1525-32.e1. doi: 10.1016/j.cgh.2018.09.033

24. Papamichael K, Chachu KA, Vajravelu RK, Vaughn BP, Ni J, Osterman MT, et al. Improved long-term outcomes of patients with inflammatory bowel disease receiving proactive compared with reactive monitoring of serum concentrations of infliximab. Clin Gastroenterol Hepatol. (2017) 15:1580-8.e3. doi: 10.1016/j.cgh.2017.03.031

25. Vande Casteele N, Ferrante M, Van Assche G, Ballet V, Compernolle G, Van Steen $\mathrm{K}$, et al. Trough concentrations of infliximab guide dosing for patients with inflammatory bowel disease. Gastroenterology. (2015) 148:1320-9.e3. doi: 10.1053/j.gastro.2015.02.031

26. D'Haens G, Vermeire S, Lambrecht G, Baert F, Bossuyt P, Pariente B, et al. Increasing infliximab dose based on symptoms, biomarkers, and serum drug concentrations does not increase clinical, endoscopic, and corticosteroid-free remission in patients with active luminal Crohn's disease. Gastroenterology. (2018) 154:1343-51.e1. doi: 10.1053/j.gastro.2018.01.004

27. Assa A, Matar M, Turner D, Broide E, Weiss B, Ledder O, et al. Proactive monitoring of adalimumab trough concentration associated with increased clinical remission in children with Crohn's disease compared with reactive monitoring. Gastroenterology. (2019) 157:985-96.e2. doi: 10.1053/j.gastro.2019.06.003

28. Lyles JL, Mulgund AA, Bauman LE, Su W, Fei L, Chona DL, et al. Effect of a practice-wide anti-TNF proactive therapeutic drug monitoring program on outcomes in pediatric patients with inflammatory bowel disease. Inflamm Bowel Dis. (2020) 27:482-92. doi: 10.1093/ibd/izaa102

29. Feuerstein JD, Nguyen GC, Kupfer SS, Falck-Ytter Y, Singh S, American Gastroenterological Association Institute Clinical Guidelines Committee. American Gastroenterological Association Institute guideline on therapeutic drug monitoring in inflammatory bowel disease. Gastroenterology. (2017) 153:827-34. doi: 10.1053/j.gastro.2017.08.006

30. Mitrev N, Vande Casteele N, Seow CH, Andrews JM, Connor SJ, Moore GT, et al. Review article: consensus statements on therapeutic drug monitoring of anti-tumour necrosis factor therapy in inflammatory bowel diseases. Aliment Pharmacol Ther. (2017) 46:1037-53. doi: 10.1111/apt.14368

31. Guidi L, Pugliese D, Panici Tonucci T, Berrino A, Tolusso B, Basile M, et al. Therapeutic drug monitoring is more cost-effective than a clinically based approach in the management of loss of response to infliximab in inflammatory bowel disease: an observational multicentre study. J Crohns Colitis. (2018) 12:1079-88. doi: 10.1093/ecco-jcc/jjy076

32. Ricciuto A, Dhaliwal J, Walters TD, Griffiths AM, Church PC. Clinical outcomes with therapeutic drug monitoring in inflammatory bowel disease: a systematic review with meta-analysis. J Crohns Colitis. (2018) 12:1302-15. doi: 10.1093/ecco-jcc/jjy109

33. Shah R, Hoffman GR, El-Dallal M, Goldowsky AM, Chen Y, Feuerstein JD. Is therapeutic drug monitoring for anti-tumor necrosis factor agents in adults with inflammatory bowel disease ready for standard of care?: a systematic review and meta-analysis. J Crohns Colitis. (2020) 14:1057-65. doi: 10.1093/ecco-jcc/jjaa029

34. Wren AA, Park KT. Targeted dosing as a precision health approach to pharmacotherapy in children with inflammatory bowel disease. AMA J Ethics. (2018) 20:E841-8. doi: 10.1001/amajethics.2018.841

35. Feagan BG, Rutgeerts P, Sands BE, Hanauer S, Colombel JF, Sandborn WJ, et al. Vedolizumab as induction and maintenance therapy for ulcerative colitis. N Engl J Med. (2013) 369:699-710. doi: 10.1056/NEJMoa1215734

36. Sandborn WJ, Feagan BG, Rutgeerts P, Hanauer S, Colombel JF, Sands BE, et al. Vedolizumab as induction and maintenance therapy for Crohn's disease. N Engl J Med. (2013) 369:711-21. doi: 10.1056/NEJMoa1215739

37. Rosario M, French JL, Dirks NL, Sankoh S, Parikh A, Yang H, et al. Exposure-efficacy relationships for vedolizumab induction therapy in patients with ulcerative colitis or Crohn's disease. J Crohns Colitis. (2017) 11:921-9. doi: $10.1093 /$ ecco-jcc/jjx021

38. Dreesen E, Verstockt B, Bian S, de Bruyn M, Compernolle G, Tops S, et al. Evidence to support monitoring of vedolizumab trough concentrations in patients with inflammatory bowel diseases. Clin Gastroenterol Hepatol. (2018) 16:1937-46.e8. doi: 10.1016/j.cgh.2018.04.040

39. Ungaro RC, Yarur A, Jossen J, Phan BL, Chefitz E, Sehgal P, et al. Higher trough vedolizumab concentrations during maintenance therapy are associated with corticosteroid-free remission in inflammatory bowel disease. J Crohns Colitis. (2019) 13:963-9. doi: 10.1093/ecco-jcc/jjz041

40. Yacoub W, Williet N, Pouillon L, Di-Bernado T, De Carvalho Bittencourt M, Nancey S, et al. Early vedolizumab trough levels predict mucosal healing in inflammatory bowel disease: a multicentre prospective observational study. Aliment Pharmacol Ther. (2018) 47:906-12. doi: 10.1111/apt.14548

41. Peyrin-Biroulet L, Danese S, Argollo M, Pouillon L, Peppas S, GonzalezLorenzo $\mathrm{M}$, et al. Loss of response to vedolizumab and ability of dose intensification to restore response in patients with Crohn's disease or ulcerative colitis: a systematic review and meta-analysis. Clin Gastroenterol Hepatol. (2019) 17:838-46.e2. doi: 10.1016/j.cgh.2018.06.026

42. Van den Berghe N, Verstockt B, Gils A, Ferrante M, Vermeire S, Thomas D. 238 vedolizumab concentrations in colonic mucosal tissue of ulcerative colitis patients inversely correlate with the severity of inflammation. Gastroenterology. (2020) 158:S47. doi: 10.1016/S0016-5085(20)30799-X 
43. Sandborn WJ, Baert F, Danese S, Krznaric Z, Kobayashi T, Yao X, et al. Efficacy and safety of vedolizumab subcutaneous formulation in a randomized trial of patients with ulcerative colitis. Gastroenterology. (2020) 158:562-72.e12. doi: 10.1053/j.gastro.2019.08.027

44. Maaser C, Sturm A, Vavricka SR, Kucharzik T, Fiorino G, Annese V, et al. ECCO-ESGAR guideline for diagnostic assessment in IBD part 1: initial diagnosis, monitoring of known IBD, detection of complications. J Crohns Colitis. (2019) 13:144-64. doi: 10.1093/ecco-jcc/jjy113

45. Aardoom MA, Jongsma MME, de Vries A, Wolthoorn J, de Ridder L, Escher JC. Vedolizumab trough levels in children with anti-tumor necrosis factor refractory inflammatory bowel disease. J Pediatr Gastroenterol Nutr. (2020) 71:501-7. doi: 10.1097/MPG.0000000000002833

46. Battat R, Kopylov U, Bessissow T, Bitton A, Cohen A, Jain A, et al. Association between ustekinumab trough concentrations and clinical, biomarker, and endoscopic outcomes in patients with Crohn's disease. Clin Gastroenterol Hepatol. (2017) 15:1427-34.e2. doi: 10.1016/j.cgh.2017.03.032

47. Adedokun OJ, Xu Z, Gasink C, Jacobstein D, Szapary P, Johanns J, et al. Pharmacokinetics and exposure response relationships of ustekinumab in patients with Crohn's disease. Gastroenterology. (2018) 154:1660-71. doi: 10.1053/j.gastro.2018.01.043

48. Hanauer SB, Sandborn WJ, Feagan BG, Gasink C, Jacobstein D, Zou B, et al. IM-UNITI: three-year efficacy, safety, and immunogenicity of ustekinumab treatment of Crohn's disease. J Crohns Colitis. (2020) 14:23-32. doi: 10.1093/ecco-jcc/jjz110

49. Vermeire S, Dreesen E, Papamichael K, Dubinsky MC. How, when, and for whom should we perform therapeutic drug monitoring? Clin Gastroenterol Hepatol. (2020) 18:1291-9. doi: 10.1016/j.cgh.2019. 09.041

50. Dubinsky MC, Phan BL, Singh N, Rabizadeh S, Mould DR. Pharmacokinetic dashboard-recommended dosing is different than standard of care dosing in infliximab-treated pediatric IBD patients. AAPS J. (2017) 19:215-22. doi: 10.1208/s12248-016-9994-y

51. Fuchs A, Csajka C, Thoma Y, Buclin T, Widmer N. Benchmarking therapeutic drug monitoring software: a review of available computer tools. Clin Pharmacokinet. (2013) 52:9-22. doi: 10.1007/s40262-012-0020-y

52. Strik AS, Lowenberg M, Mould DR, Berends SE, Ponsioen CI, van den Brande $\mathrm{JMH}$, et al. Efficacy of dashboard driven dosing of infliximab in inflammatory bowel disease patients a randomized controlled trial. Scand J Gastroenterol. (2021) 56:145-54. doi: 10.1080/00365521.2020.1856405

53. Strik A, Berends S, Mould D, Mathôt R, Ponsioen C, van den Brande J, et al. DOP56 dashboard driven vs. conventional dosing of infliximab in inflammatory bowel disease patients: the PRECISION trial. J Crohn Colitis. (2019) 13(Suppl. 1):S063. doi: 10.1093/ecco-jcc/jjy222.090

54. Dubinsky M, Phan BL, Lega S, Tse S, Kline MR, Novack DE, et al. Mo1838 - pharmacokinetic dashboard-driven infliximab dosing in IBD:a prospective interventional study. Gastroenterology. (2018) 154:S820. doi: 10.1016/S0016-5085(18)32802-6

55. Dubinsky M, Phan BL, Tse S, Mould DR. 240 real-world application of an adaptive dosing dashboard reveals accelerated induction dosing of infliximab is necessary in most IBD patients and improves therapuetic outcomes. Gastroenterology. (2020) 158:S47-8. doi: 10.1016/S0016-5085(20)30801-5

56. Neely MN, Kato L, Youn G, Kraler L, Bayard D, van Guilder M, et al. Prospective trial on the use of trough concentration versus area under the curve to determine therapeutic vancomycin dosing. Antimicrob Agents Chemother. (2018) 62:e02042-17. doi: 10.1128/AAC.02042-17

57. Felton TW, Roberts JA, Lodise TP, Van Guilder M, Boselli E, Neely MN, et al. Individualization of piperacillin dosing for critically ill patients: dosing software to optimize antimicrobial therapy. Antimicrob Agents Chemother. (2014) 58:4094-102. doi: 10.1128/AAC.02664-14

58. Laserna-Mendieta EJ, Salvador-Martin S, Arias-Gonzalez L, Ruiz-Ponce M, Menchen LA, Sanchez C, et al. Comparison of a new rapid method for the determination of adalimumab serum levels with two established ELISA kits. Clin Chem Lab Med. (2019) 57:1906-14. doi: 10.1515/cclm-2019-0202

59. Nasser Y, Labetoulle R, Harzallah I, Berger AE, Roblin X, Paul S. Comparison of point-of-care and classical immunoassays for the monitoring infliximab and antibodies against infliximab in IBD. Dig Dis Sci. (2018) 63:2714-21. doi: 10.1007/s10620-018-5144-y
60. Van Stappen T, Bollen L, Vande Casteele N, Papamichael K, Van Assche G, Ferrante $M$, et al. Rapid test for infliximab drug concentration allows immediate dose adaptation. Clin Transl Gastroenterol. (2016) 7:e206. doi: $10.1038 /$ ctg. 2016.62

61. Bossuyt P, Hoefkens E, Geerts I, Verbiest F, Vermeulen E, Van Olmen A, et al. Tu1818 - ultra-proactive therapeutic drug monitoring incorporating infliximab point-of-care testing with ad hoc dose adjustment reduces C-reactive protein levels in patients with IBD during infliximab maintenance treatment. Gastroenterology. (2019) 156:S1136. doi: 10.1016/S0016-5085(19)39804-X

62. Curci D, Lucafo M, Cifu A, Bramuzzo M, Martelossi S, Favretto D, et al. Determination of serum infliximab concentration by point-of-care devices in children with inflammatory bowel disease. J Pediatr Gastroenterol Nutr. (2019) 69:474-9. doi: 10.1097/MPG.0000000000002410

63. Benchimol EI, Mack DR, Nguyen GC, Snapper SB, Li W, Mojaverian N, et al. Incidence, outcomes, and health services burden of very early onset inflammatory bowel disease. Gastroenterology. (2014) 147:803-13.e7; quiz e14-5. doi: 10.1053/j.gastro.2014.06.023

64. Kammermeier J, Dziubak R, Pescarin M, Drury S, Godwin H, Reeve K, et al. Phenotypic and genotypic characterisation of inflammatory bowel disease presenting before the age of 2 years. J Crohns Colitis. (2017) 11:60-9. doi: 10.1093/ecco-jcc/jjw118

65. Bramuzzo M, Arrigo S, Romano C, Filardi MC, Lionetti P, Agrusti A, et al. Efficacy and safety of infliximab in very early onset inflammatory bowel disease: a national comparative retrospective study. United Eur Gastroenterol J. (2019) 7:759-66. doi: 10.1177/2050640619847592

66. Kelsen JR, Grossman AB, Pauly-Hubbard H, Gupta K, Baldassano $\mathrm{RN}$, Mamula P. Infliximab therapy in pediatric patients 7 years of age and younger. J Pediatr Gastroenterol Nutr. (2014) 59:758-62. doi: 10.1097/MPG.0000000000000533

67. de Bruyn JC, Jacobson K, El-Matary W, Carroll M, Wine E, Wrobel I, et al. Long-term outcomes of infliximab use for pediatric Crohn's disease: a canadian multicenter clinical practice experience. J Pediatr Gastroenterol Nutr. (2018) 66:268-73. doi: 10.1097/MPG.0000000000001672

68. Fasanmade AA, Adedokun OJ, Blank M, Zhou H, Davis HM. Pharmacokinetic properties of infliximab in children and adults with Crohn's disease: a retrospective analysis of data from 2 phase III clinical trials. Clin Ther. (2011) 33:946-64. doi: 10.1016/j.clinthera.2011.06.002

69. Assa A, Dorfman L, Shouval DS, Shamir R, Cohen S. Therapeutic drug monitoring guided high dose infliximab for infantile-onset inflammatory bowel disease: a case series. J Pediatr Gastroenterol Nutr. (2020) 71:516-20. doi: 10.1097/MPG.0000000000002832

70. Jongsma MME, Winter DA, Huynh HQ, Norsa L, Hussey S, Kolho KL, et al. Infliximab in young paediatric IBD patients: it is all about the dosing. Eur J Pediatr. (2020) 179:1935-44. doi: 10.1007/s00431-020-03750-0

71. Sazonovs A, Kennedy NA, Moutsianas L, Heap GA, Rice DL, Reppell M, et al. HLA-DQA1*05 carriage associated with development of anti-drug antibodies to infliximab and adalimumab in patients with Crohn's disease. Gastroenterology. (2020) 158:189-99. doi: 10.1053/j.gastro.2019.09.041

72. Yarur AJ, Jain A, Sussman DA, Barkin JS, Quintero MA, Princen F, et al. The association of tissue anti-TNF drug levels with serological and endoscopic disease activity in inflammatory bowel disease: the ATLAS study. Gut. (2016) 65:249-55. doi: 10.1136/gutjnl-2014-308099

73. Peyrin-Biroulet L, Sandborn W, Sands BE, Reinisch W, Bemelman W, Bryant $\mathrm{RV}$, et al. Selecting therapeutic targets in inflammatory bowel disease (stride): determining therapeutic goals for treat-to-target. Am J Gastroenterol. (2015) 110:1324-38. doi: 10.1038/ajg.2015.233

74. Yarur AJ, Kanagala V, Stein DJ, Czul F, Quintero MA, Agrawal D, et al. Higher infliximab trough levels are associated with perianal fistula healing in patients with Crohn's disease. Aliment Pharmacol Ther. (2017) 45:933-40. doi: 10.1111/apt.13970

75. Vande Casteele N, Jeyarajah J, Jairath V, Feagan BG, Sandborn WJ. Infliximab exposure-response relationship and thresholds associated with endoscopic healing in patients with ulcerative colitis. Clin Gastroenterol Hepatol. (2019) 17:1814-21.e1. doi: 10.1016/j.cgh.2018.10.036

76. Stein R, Lee D, Leonard MB, Thayu M, Denson LA, Chuang E, et al. Serum infliximab, antidrug antibodies, and tumor necrosis factor predict sustained 
response in pediatric Crohn's disease. Inflamm Bowel Dis. (2016) 22:1370-7. doi: 10.1097/MIB.0000000000000769

77. Hoekman DR, Brandse JF, de Meij TG, Hummel TZ, Lowenberg M, Benninga MA, et al. The association of infliximab trough levels with disease activity in pediatric inflammatory bowel disease. Scand J Gastroenterol. (2015) 50:11107. doi: $10.3109 / 00365521.2015 .1027264$

78. Zitomersky NL, Atkinson BJ, Fournier K, Mitchell PD, Stern JB, Butler MC, et al. Antibodies to infliximab are associated with lower infliximab levels and increased likelihood of surgery in pediatric IBD. Inflamm Bowel Dis. (2015) 21:307-14. doi: 10.1097/MIB.0000000000000284

79. Sharma S, Eckert D, Hyams JS, Mensing S, Thakkar RB, Robinson AM, et al. Pharmacokinetics and exposure-efficacy relationship of adalimumab in pediatric patients with moderate to severe Crohn's disease: results from a randomized, multicenter, phase-3 study. Inflamm Bowel Dis. (2015) 21:78392. doi: 10.1097/MIB.0000000000000327

80. Minar P, Saeed SA, Afreen M, Kim MO, Denson LA. Practical use of infliximab concentration monitoring in pediatric Crohn's disease. J Pediatr Gastroenterol Nutr. (2016) 62:715-22. doi: 10.1097/MPG.00000000000 01029

81. Dubinsky MC, Rosh J, Faubion WA Jr, Kierkus J, Ruemmele F, Hyams JS, et al. Efficacy and safety of escalation of adalimumab therapy to weekly dosing in pediatric patients with Crohn's disease. Inflamm Bowel Dis. (2016) 22:886-93. doi: 10.1097/MIB.000000000000 0715

82. Chi LY, Zitomersky NL, Liu E, Tollefson S, Bender-Stern J, Naik S, et al. The impact of combination therapy on infliximab levels and antibodies in children and young adults with inflammatory bowel disease. Inflamm Bowel Dis. (2018) 24:1344-51. doi: 10.1093/ibd/izy010

83. van Hoeve K, Hoffman I, Vermeire S. Therapeutic drug monitoring of antiTNF therapy in children with inflammatory bowel disease. Expert Opin Drug Saf. (2018) 17:185-96. doi: 10.1080/14740338.2018.1413090

84. Ohem J, Hradsky O, Zarubova K, Copova I, Bukovska P, Prusa R, et al. Evaluation of infliximab therapy in children with Crohn's disease using trough levels predictors. Dig Dis. (2018) 36:40-8. doi: 10.1159/000477962
85. van Hoeve K, Dreesen E, Hoffman I, Van Assche G, Ferrante M, Gils A, et al. Adequate infliximab exposure during induction predicts remission in paediatric patients with inflammatory bowel disease. J Pediatr Gastroenterol Nutr. (2019) 68:847-53. doi: 10.1097/MPG.0000000000002265

86. Choi SY, Kang B, Choe YH. Serum infliximab cutoff trough level values for maintaining hematological remission in pediatric inflammatory bowel disease. Gut Liver. (2019) 13:541-8. doi: 10.5009/gnl18129

87. Naviglio S, Lacorte D, Lucafo M, Cifu A, Favretto D, Cuzzoni E, et al. Causes of treatment failure in children with inflammatory bowel disease treated with infliximab: a pharmacokinetic study. J Pediatr Gastroenterol Nutr. (2019) 68:37-44. doi: 10.1097/MPG.0000000000002112

88. Clarkston K, Tsai YT, Jackson K, Rosen MJ, Denson LA, Minar P. Development of infliximab target concentrations during induction in pediatric Crohn's disease patients. J Pediatr Gastroenterol Nutr. (2019) 69:6874. doi: 10.1097/MPG.0000000000002304

89. Gofin Y, Matar M, Shamir R, Assa A. Therapeutic drug monitoring increases drug retention of anti-tumor necrosis factor alpha agents in pediatric patients with Crohn's disease. Inflamm Bowel Dis. (2020) 26:1276-82. doi: 10.1093/ibd/izz257

90. Choi SY, Choi YO, Choe YH, Kang B. Potential utility of therapeutic drug monitoring of adalimumab in predicting short-term mucosal healing and histologic remission in pediatric Crohn's disease patients. J Korean Med Sci. (2020) 35:e114. doi: 10.3346/jkms.2020.35.e114

Conflict of Interest: The authors declare that the research was conducted in the absence of any commercial or financial relationships that could be construed as a potential conflict of interest.

Copyright $\odot 2021$ Kapoor and Crowley. This is an open-access article distributed under the terms of the Creative Commons Attribution License (CC BY). The use, distribution or reproduction in other forums is permitted, provided the original author(s) and the copyright owner(s) are credited and that the original publication in this journal is cited, in accordance with accepted academic practice. No use, distribution or reproduction is permitted which does not comply with these terms. 